\title{
ETNOGRAFI VIRTUAL PADA LAMAN PENGGUNA INSTAGRAM STORIES (IG STORIES) SEBAGAI BENTUK KOMUNIKASI INTERPERSONAL
}

\author{
Akira Aulia Witri dan Mutia Rahmi Pratiwi \\ Universitas Dian Nuswantoro \\ akiraauliaw@gmail.com
}

\begin{abstract}
Abstrak
Perkembangan media sosial di Indonesia berdampak pada penggunanya, terutama bagi remaja. Instagram merupakan salah satu media sosial yang digunakan oleh para remaja untuk menunjukan eksistensinya melalui berbagai informasi yang diunggah. Instagram Stories (IG Stories) merupakan salah satu fitur di Instagram yang memiliki banyak pengguna. Fitur IG Stories menjadi media pengungkapan diri melalui unggahan berupa foto, teks, video yang didukung dengan filter didalamnya. Penelitian ini merupakan penelitian kualitatif dengan metode etnografi virtual. Subjek penelitian terdiri dari dua orang yaitu Icak dan Rizky, remaja berusia 18 dan 23 tahun yang aktif menggunakan IG Stories di akun pribadinya. Hasil penelitian menunjukan bahwa terdapat lima aspek dalam pengungkapan diri yang melatarbelakangi pengguna fitur IG stories, yaitu: (1) Berdasarkan aspek ketepatan, para informan mengunggah konten yang relevan dengan kegiatan yang sedang dilakukan; (2) Berdasarkan aspek motivasi, para informan termotivasi untuk mengungkapkan dirinya karena adanya dorongan dari luar dan dalam melalui setiap foto yang diposting; (3) Berdasarkan aspek waktu, para informan memposting foto pada pagi, siang dan malam hari; (4) Berdasarkan aspek keintensifan yang ditunjukan oleh para informan kepada siapa ia mengungkapkan dirinya; (5) Berdasarkan aspek kedalaman, para informan melakukan postingan di IG Stories yang ditujukan kapada semua follower di akunnya.
\end{abstract}

Kata Kunci: Self Disclosure, Instagram Stories, Remaja.

\begin{abstract}
The development of social media in Indonesia has an impact on its users, especially for teenagers. Instagram is one of the social media used by teenagers to show their existence through various uploaded information. Instagram Stories (IG Stories) is one of the features on Instagram that has many users. IG Stories feature is a medium for self disclosure through uploads of photos, text, videos that are supported by filters inside. This research is a qualitative research with virtual ethnographic methods. The research subjects consisted of two people, Icak and Rizky, adolescents aged 18 and 23 years who actively used IG Stories in their personal accounts. The results of the study describe a five aspect of instagram stories feature. Five aspect of self disclosure which is influence the user of Instagram Stories feature: (1) Accuracy, the informants uploaded content that was relevant to the activities being carried out;(2) Motivation aspect, the informant is motivated to express himself because of the encouragement from inside and outside through each photo posted; (3)The time aspect, the informant posted a photo in the morning, afternoon and evening; (4) The intensification aspect, which is indicated by the informant to whom he revealed himself; (5) The depth aspect, the informant posting on instagram stories is directed to all followers or to certain accounts on his instagram.
\end{abstract}




\section{Pendahuluan}

New media adalah media yang terbentuk dari interaksi antara manusia dengan komputer dan internet secara khususnya, termasuk web, blog, online social network, social media, online forum dan lain-lain menggunakan komputer sebagai medianya (Flew dalam Ardianto, 2007: 69). Individu tidak lagi mengandalkan tatap muka untuk berkomunikasi satu sama lain, melainkan memanfaatkan teknologi komunikasi. Berbagai perubahan terjadi akibat munculnya media baru, salah satunya adalah munculnya sebuah budaya populer. Media sosial yang mulai bermunculan saat ini telah mengubah cara penyampaian dan penerimaan informasi pada masyarakat. Setiap orang menggunakan media sosial sebagai sarana untuk berkomunikasi, membuat status, berkomentar, berbagi foto dan video layaknya ketika kita berada dalam lingkungan sosial.

Kemudahan dalam mengakses internet menjadikan pengguna media sosial semakin meningkat bahkan media sosial menjadi salah satu lifestyle trending. Popularitas penggunaan media sosial di kalangan generasi abad ini tidak terlepas dari fungsinya yang mampu menjadi sarana presentasi diri guna mendukung eksistensi pribadi sebagai manusia. Media sosial menurut Meike dan Young (dalam Nasrullah, 2015 : 11) merupakan konvergensi antara komunikasi personal dalam arti saling berbagi di antara individu dan media publik untuk berbagi kepada siapapun tanpa ada kekhususan individu. Social Networking atau jejaring sosial yang merupakan medium terpopuler dalam kategori media sosial (Nasrullah, 2015 : 40). Bentuk media baru diantaranya adalah facebook, instagram, twitter. Namun diantara ketiganya, instragram menjadi media sosial yang memiliki kekuatan di visual, video, dan text.

Instagram merupakan sosial media baru yang hadir di ranah jejaring sosial yang meraih popularitas sangat tinggi hingga kini menjadi sangat terkenal di kalangan anak muda hingga dewasa. Instagram selalu mengembangkan fitur-fiturnya dimana ketika awal diluncurkan, instagram hanya dapat digunakan untuk mengunggah foto saja. Pada tahun 2013 terjadi perkembangan dimana pengguna Instagram dapat mengunggah video. Hal ini membuat Instagram menjadi semakin digemari oleh masyarakat. Masyarakat yang mengikuti dan menggunakan media sosial tersebut menunjukkan berbagai aktivitas kesehariannya dengan mengabadikan dan mengunggahnya ke media sosial Instagram. Melalui gaya foto dan captionnya lah yang nantinya akan dapat menunjukkan karakter dari para pengguna dan juga bagaimana seseorang menggambarkan sosok atau jati diri yang diinginkannya. Survei menunjukkan bahwa Instagram menduduki peringkat nomor 4 konten media yang sering digunakan oleh masyarakat, data sebagai berikut : 
Gambar1

Grafik Platform Media Sosial Paling Aktif di Indonesia

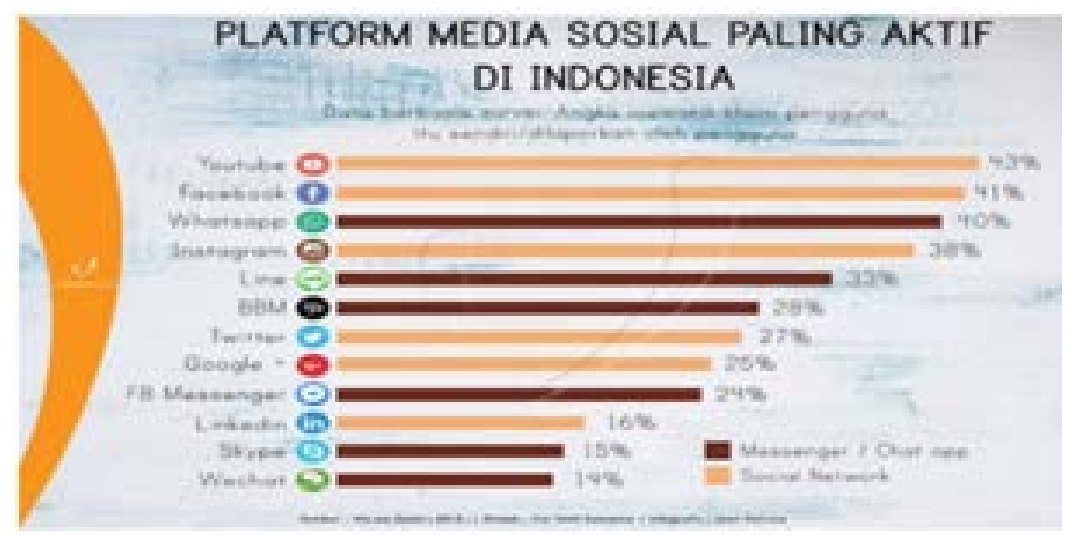

Sumber : diunduh dari https://www.validnews.id/infografis-Platform-Media-SosialPaling-Aktif-Di-Indonesia-QJ

Berdasarkan hasil survei diatas bahwa Instagram, berada pada posisi ke4 setelah Facebook dengan presentase $38 \%$ yang paling sering digunakan. Berdasarkan penelitian lainnya pada tahun 2018 bahwa pengguna Instagram berdasarkan umur adalah sebagai berikut :

Gambar 2.

Grafik Data Umur Pengguna Instagram

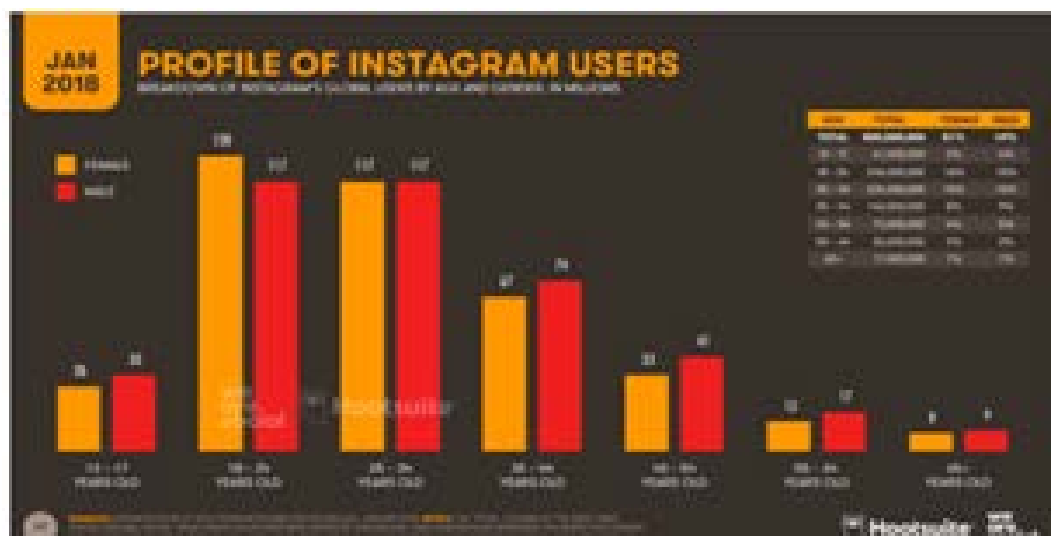

Sumber: diunduh dari https://kekitaan.com/layanan-kita/data-pengguna-instagram-perumur

Berdasarkan hasil survei diatas bahwa pengguna Instagram berdasarkan umur 18-24 tahun adalah yang terbanyak, yaitu $40 \%$. Hal tersebut merupakan usia remaja yang banyak menggunakan Instagram sebagai salah satu media sosial yang mereka gunakan. Berdasar hasil survei We Are Social.net dan Hootsuite, Instagram juga merupakan platform media sosial dengan jumlah pengguna terbanyak ke tujuh di dunia. Total pengguna Instagram di 
dunia mencapai angka 800 juta pada Januari 2018.

Media Sosial telah membuka kemungkinan baru untuk berbagi informasi pribadi dengan jaringan online, dan jutaan orang secara rutin mengungkapkan informasi pribadi di berbagi media sosial. Pemilik profil atau pengguna di media sosial secara aktif menggunakan profilnya sebagai ajang untuk berekspresi dan mengungkapkan atas dirinya. Seperti halnya salah satu seorang public figure yaitu Dian Sastrowardoyo dalam akun Instagramnya @ therealdisastr yang selalu mengungkapkan dirinya dengan mengunggah foto atau video dengan berbagai macam aktivitas setiap harinya melalui fitur Instagram yaitu Instagram Stories untuk membuat publik memberikan image bahwa Dian Sastrowardoyo merupakan artis yang sangat aktif dan kekinian.

Media sosial mempermudah seseorang untuk memperluas pertemanan dari daerah yang berbeda. Hasil observasi menunjukkan bahwa kecenderungan pada masalah ini yang adalah kegunaan media sosial itu sendiri digunakan oleh penggunanya sebagai alat untuk pengungkapan diri (self disclousure). Trenholm (2004: 5) menyatakan bahwa seseorang memiliki berbagai pertimbangan utama ketika berkomunikasi melalui internet yang sama seperti komunikasi tatap muka, yaitu memiliki kesamaan sikap, saling menyukai satu sama lain, saling melontarkan humor pengungkapan diri di media sosial merupakan hal yang biasa dan lumrah pada saat ini, bahkan terkadang media sosial pada saat ini dibuat seperti catatan harian atau lebih seperti buku harian.

Pengungkapan diri (self disclosure) dapat terjadi, jika seseorang dapat membuka dirinya dan berbagai informasi mengenai dirinya kepada orang lain. Pengungkapan diri ini dapat berupa informasi, sikap, perilaku dan perasaan yang bersangkutan. Pengungkapan diri adalah aspek intimacy, yakni sejauh mana derajat informasi itu mencerminkan orang yang bersangkutan secara personal atau pribadi atau perasaan-perasaan yang paling dalam diri sendiri. Pengungkapan diri seseorang dapat mencapai tahap hubungan interpersonal yang dapat dilihat dari tingkat kedalaman dan keluasan topik pembicaraan. Individu yang menginformasikan segala hal mengenai dirinya kepada siapapun disebut over disclosure sedangkan individu yang menutup dirinya atau jarang membicarakan dirinya kepada siapapun disebut under disclosure.

Berikut ini data peningkatan pemgguna media sosial dari tahun 2017-2018 berdasarkan hasil penelitian eMarketer.com: 


\section{Gambar 3.}

Grafik pengguna media sosial di seluruh dunia meningkat tahun 2017-2018

\begin{tabular}{|c|c|c|c|c|c|c|}
\hline \multicolumn{7}{|c|}{$\begin{array}{l}\text { Top } 25 \text { Cowhtries. Eanked by internet Uven. } 20132011 \\
\text { callons }\end{array}$} \\
\hline & 204 & 2ose & 2015 & 204 & 20 & 201 \\
\hline Coing & 007 & $\mathbf{s 3 4}$ & tat & $7 \times 1$ & $7 x 2$ & $m$ \\
\hline $65^{* t}$ & & & & & & 201 \\
\hline nda & wi & 286 & xa) & 201 & 303 & 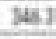 \\
\hline past & พ2 & wol & 147 & 148 & tas & 751 \\
\hline 1 xon & 1000 & 191 & Eis & was & 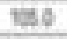 & 1084 \\
\hline i rocksa & & & & & & 192 \\
\hline 7 katas & $n 3$ & & (2) & & & \\
\hline 1 carras & 205 & St6 & 62 & 63 & 2. & 42) \\
\hline 1 Wees & a1 & 84 & 551 & 6) & 787 & 304 \\
\hline 96 bova & 118 & DI & 692 & wi & 23 & 43 \\
\hline ntger & at & set & 513 & 84 & 54 & 43. \\
\hline 4 Frang & & & & & & 121 \\
\hline is hiserere & c) & ab & (1) & 301 & us & 61 \\
\hline
\end{tabular}

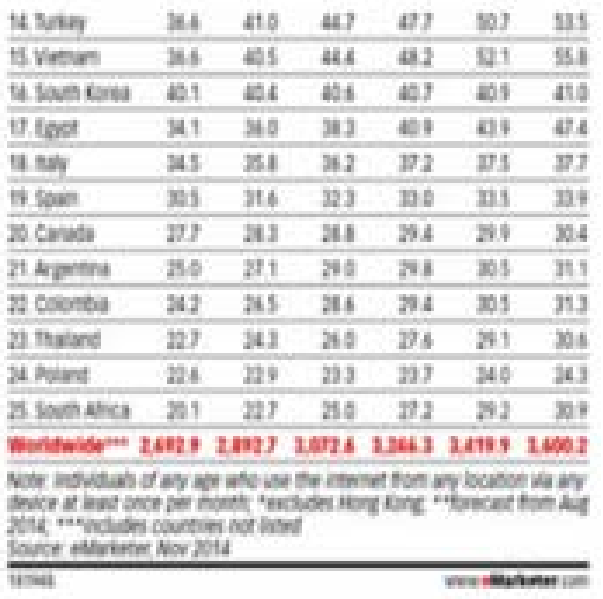

Sumber : diunduh dari https://kominfo.go.id/content/detail/4286/pengguna-internetindonesia-nomor-enam-dunia/0/sorotan_media

Instagram yang telah memiliki 22 juta pengguna aktif bulanan di Indonesia kini telah meluncurkan fitur baru yaitu Instagram Stories dengan jumlah pengguna aktifnya sebanyak 100 juta per harinya (https://www.cnnindonesia.com/ teknologi/20160623112758-185-140353/ada-22-juta-pengguna-aktif-instagramdari-indonesia, diakses tanggal 27 Juni 2019). Instagram Stories memungkinkan penggunanya untuk mengambil foto, video, serta menerapkan filter digital kemudian dapat membagikannya hanya selama 24 jam. Konten yang diunggah melalui Instagram Stories tidak akan muncul pada profil grid maupun Feed (https://tekno.kompas.com/ read/2018/10/06/10512437/hari-ini-dalam-sejarah-aplikasi-instagram-dirilis, diakses pada tanggal 20 Mei 2019).

Melalui fitur Instagram Stories, seseorang dapat dengan bebas berbagi berbagai aktivitas mereka, seperti: informasi umum, video dan foto kegiatan sehari-hari, dan foto outfit of the day. Curahan hati pengguna instagram merupakan salah satu aktivitas yang paling populer untuk dibagikan kedalam Instagram Stories sehingga memunculkan citra diri. Berdasarkan hasil observasi yang dilakukan, saat ini, seseorang lebih nyaman mengungkapkan dirinya pada sosial media dengan curhat di akun sosial media pribadinya.

Keterbukaan informasi pribadi di media sosial dapat menimbulkan dampak negatif, salah satunya adalah kasus pelecehan seksual di media sosial yang dialami oleh Adiezty Fersa. la mendapatkan komentar tidak senonoh ketika sedang live di Instagram Stories, seperti “Buka baju dong"(https://kumparan.com/@kumparanhits/pernah-dapatpelecehan-istri-gilang-dirga-enggak-kapok-main-medsos, diakses 27 Juni 2019). Dampak negatif lainnya adalah bullying yang dialami oleh Dian Sastro di akunnya @therealdisastr. Dian Sastrowardoyo banyak menerima sindiran dari para netizennya karena sering 
menggugah aktivitasnya hingga puluhan kali selama 24 jam dalam sehari sehingga muncul titik-titik kecil di IG story nya. Hal ini berdampak pada munculnya berbagai meme lucu oleh para netizen (http://lampung.tribunnews.com/2018/03/18/biasa-dipuja-dian-sastrobanjir-bully-gara-gara-foto-ini-netizen-merasa-tertipu-dengan-sosoknya, diakses tanggal 13 April 2019).

Gambar 4.

Meme Instagram Stories Dian Sastro

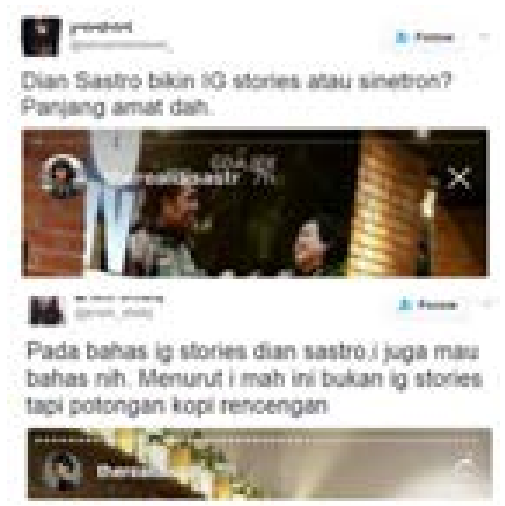

Sumber : diunduh dari https://www.hipwee.com

Pengungkapan diri yang dinilai berlebihan di media sosial seringkali menjadi masalah bagi pengguna sendiri diantaranya memicu tindak criminal baik di dunia nyata maupun di dunia maya. Kehadiran media sosial menyebabkan meleburnya ruang privasi dan ruang pubik seseorang. Hal ini dapat dilihat dari perilaku remaja yang mengungkapkan diri secara aktif dengan mengunggah (upload) segala kegiatan pribadinya untuk disampaikan kepada teman-temannya melalui akun pribadi. Para remaja merasa nyaman ketika dapat mengunggah informasi-informasi yang sifatnya pribadi karena hal ini merupakan bagian dari pengungkapan diri yang berbeda bagi setiap individu.

Indonesia memiliki 53 juta jumlah pengguna aktif bulanan, dan pengguna aktif Instagram dari total populasi sekitar 20 persen. Pengguna Instagram kebanyakan adalah pria yaitu sekitar 51 persen dan wanita sekitar 49 persen namun jumlah pengguna aktif instagram bulanan sebanyak 52 persen wanita dan sekitar 48 persen pria. Instagram Stories saat ini memiliki 250 juta pengguna aktif harian melampaui snapchat yang hanya memiliki 166 juta pengguna. Kota Jakarta saat ini menempati urutan pertama sebagai lokasi yang paling banyak ditandai di Instagram. Instagram menjadi lebih menarik bagi remaja dikarenakan belum banyak orang tua yang menggunakannya sehingga para remaja lebih bebas berekspresi dan berkomunikasi melalui instagram(https://tekno. kompas.com/read/2018/03/01/10340027/riset-ungkap-pola-pemakaian-medsos-orangindonesia, diakses pada tanggal 1 Maret 209). 
Brand Development Lead Instagram APAC Paul Webster, dilansir dari Okezone.com (14/1/2016) mengungkapkan, "Instagrammer mayoritas anak muda, terdidik dan mapan. Rata-rata mereka berusia 18-24 tahun sebanyak 59\%, usia 23-35 tahun 30\%, dan yang berusia 34-44 tahun $11 \%$. Pengguna Instagram, perempuan yang paling aktif sebanyak $63 \%$ dan laki-laki 37\%. Pada data tersebut yang paling banyak dalam penggunaan Instagram adalah anak muda usia 18-24 tahun dengan jumlah presentase sebesar 59\%. Berdasarkan data yang telah dipaparkan, penulis tertarik untuk meneliti pengungkapan diri yang dilakukan remaja dalam rentang usia 18-24 tahun karena saat ini merupakan pengguna Instagram Stories terbanyak.

\section{Tujuan Penelitian}

Penelitian ini bertujuan untuk mendeskripsikan Pengungkapan Diri Remaja melalui unggahan di fitur Instagram Stories (IG Stories).

\section{Kerangka Teori}

\subsection{Teori Self Disclosure (Pengungkapan Diri)}

Self disclosure merupakan kemampuan seseorang untuk mengungkapkan informasi diri kepada orang lain yang bertujuan untuk mencapai hubungan yang akrab. Pengungkapan diri merupakan jenis komunikasi dimana seseorang mengungkapkan informasi diri yang biasanya disembunyikan sehingga terjadi proses mengungkapkan reaksi atau tanggapan diri terhadap situasi yang dihadapi serta memahami tanggapan terhadap orang lain dan sebaliknya. Membuka diri berati membagikan kepada orang lain perasaan diri terhadap suatu kejadian yang baru saja disaksikan (Devito, 2011: 64).

Individu yang mampu membuka diri akan dapat mengungkapkan diri dengan tepat; terbukti mampu menyesuaikan diri (adaptive), lebih percaya diri, lebih kompeten, dapat diandalkan, lebih mampu bersikap positif, percaya terhadap orang lain, lebih objektif dan terbuka. Individu yang kurang mampu mengungkapan diri tidak mampu menyesuaikan diri, kurang percaya diri, mengalami perasaan takut, cemas, merasa rendah diri dan tertutup (Novianna \& Heru, 2010:13). Altman \& Taylor mengemukakan 5 Aspek Self disclosure yaitu :

a) Ketepatan

Ketepatan mengacu pada apakah individu mengungkapkan informasi pribadinya sesuai dengan situasi atau keadaan yang sedang ia hadapi dan apakah individu yang bersangkutan terlibat atau tidak (sekarang dan di sini) dalam sebuah peristiwa, sesuai dengan norma-norma yang berlaku di masyarakat dalam menggunakan media sosial. Pengungkapan diri tepat berarti individu menyadari dan bertanggung jawab atas risiko yang akan ia dapatkan ketika ia mengungkapkan diri di media sosial dengan cara yang tidak sesuai dengan norma-norma penggunaan media 
sosial. Pengungkapan diri yang positif akan menimbulkan reaksi yang positif dari partisipan atau pendengar. Pengungkapan diri tidak tepat berarti individu tidak mengungkapakan informasi pribadinya sesuai dengan situasi atau keadaan yang sedang ia hadapi dan idividu tidak terlibat dalam sebuah peristiwa (disini dan sekarang).

b) Motivasi

Motivasi berkaitan dengan apa yang mendorong orang untuk mengungkapkan dirinya kepada orang lain. Dorongan yang bersangkutan berasal dari dalam diri dan dari luar. Dorongan dari dalam berkaitan dengan apa yang menjadi keinginan atau tujuan orang melakukan Self disclosure. Dorongan dari luar berasal dari lingkungan keluarga, sekolah, dan pekerjaan.

c) Waktu

Lamanya waktu yang digunakan orang saat bersama dengan orang lain akan cenderung meningkatkan kemungkinan terjadinya Self disclosure. Waktu yang tepat untuk mengungkapkan diri adalah saat individu sudah berteman atau kenal sejak lama dengan orang lain. Waktu yang kurang tepat untuk mengungkapkan diri adalah saat individu baru kenal atau bahkan tidak kenal dengan orang lain kemudian ia mengungkapkan masalah pribadinya kepada orang tersebut. Jika individu dalam keadaan kurang atau tidak baik seperti sedang sakit atau sedih, ia cenderung kurang terbuka dengan orang lain. Jika individu dalam keadaan baik seperti sedang sehat dan bahagia, ia akan cenderung terbuka dengan orang lain.

d) Keintensifan

Keintensifan seseorang dalam keterbukaan diri (Self disclosure) tergantung kepada siapa seseorang mengungkapkan diri, apakah teman dekat, orangtua, teman biasa, orang-orang yang baru dikenal.

e) Kedalaman

Kedalaman terbagi atas dua dimensi yakni Self disclosure yang dangkal dan dalam. Self disclosure yang dangkal biasanya terjadi pada orang yang baru dikenal atau semua orang. Kepada orang yang bersangkutan biasanya diceritakan aspek-aspek geografis tentang diri misalnya nama, daerah asal dan alamat. Self disclosure yang dalam, dilakukan terhadap orang-orang yang memiliki kedekatan hubungan (intimacy). Orang akan menginformasikan dirinya secara mendalam (pembicaraan lebih intim) kepada orang yang betul-betul ia percaya dan akrab dengan dirinya, misalnya orang tua, teman dekat, teman sejenis dan pacar. Kedalaman yang ideal yang terjadi bila individu dapat membedakan topik-topik (isi pembicaraan) apa saja yang sesuai untuk dibicarakan kepada orang lain dan orang-orang terdekat. Topik-topik seputar kesehatan, pekerjaan, pendidikan, 
minat atau hal-hal umum lainnya yang dapat dibicarakan kepada orang yang baru dikenal atau semua orang. Tetapi topik-topik yang menyangkut masalah pribadi seperti masalah seks hanya dibicarakan kepada terdekat seperti orang tua dan sahabat. Kedalaman yang tidak ideal terjadi bila individu mengungkapkan dirinya tanpa memandang kepada siapa ia mengungkapkan diri (Ifdil \& Zarian, 2013: 112-113).

\section{Metode Penelitian}

Jenis penelitian ini adalah penelitian kualitatif dengan metode Etnografi Virutal, yang bertujuan untuk melihat fenomena sosial dan kultur pengguna di ruang siber. Sebagai sebuah kultur dan artefak kultural, cyberspace atau dunia siber bagi penilitian etnografi virtual bisa mendekati beberapa objek atau fenomena yang ada di Internet (Nasrullah, 2014 : 171-172). Hine mengungkapkan dalam etnografi virtual fenomena yang diangkat merupakan kepingan semata, tidak menggambarkan bagaimana sesungguhnya kehidupan di Internet itu berlangsung (Hine, $2000: 63-65$ ).

Alur penelitian Etnografi Virtual dapat memanfaatkan pola yang dikembangkan oleh Spradley yang dikenal dengan nama siklus penelitian etnografi yaitu :

1. Pemilihan Proyek Etnografi

2. Pengajuan Pertanyaan Etnografi

3. Pengumpulan Data Etnografi

4. Pembuatan Rekaman Etnografi

5. Analisa Data Etnografi

6. Penilaian Sebuah Etnografi

\section{Hasil Penelitian dan Pembahasan}

\section{Subjek Penelitian}

1) Nama

Jenis Kelamin

Asal

Usia

Akun Instagram
: Rika Amelia

: Perempuan

: Medan

: 18 Tahun

: @i.cakkk 
Gambar 5.

Profile Instagram Informan 1

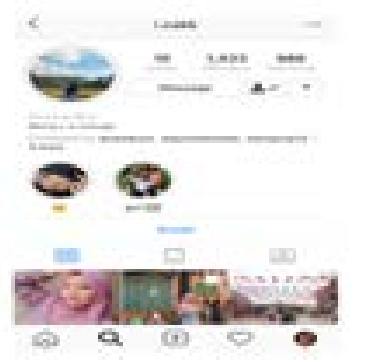

Sumber : akun instagram subjek penelitian 1

Seorang gadis berhijab yang memiliki nama lengkap Rika Amelia atau biasa dipanggil Icak ini merupakan mahasiswa semester 2 dari Universitas Muhammadiyah Sumatera Utara. Icak merupakan pengguna aktif Instagram sejak tahun 2012. Setelah perkembangan Instagram yang semakin canggih, Icak mengaku saat ini juga menggunakan Instagram Stories dalam kegiatan sehari-harinya. Didalam profilnya, Icak menggunakan nama panggilannya dan memperlihatkan wajah aslinya dengan jelas. Setiap momen menarik menurutnya akan ia posting dalam Instagram Stories miliknya. Selain itu tidak jarang pula Icak membuat Instagram Stories dengan mem-posting wajahnya dengan menggunakan filter Instagram Stories yang ada. Alasannya, karena untuk menghilangkan rasa bosan. Dalam satu hari, Icak dapat mengunggah hingga belasan Stories. Hal-hal yang biasa Icak unggah adalah mengenai kesehariannya, pasangannya, teman-teman dan keluarganya.

2) Nama : Rizky Satria Persada

Jenis Kelamin

: Laki-Laki

Asal

: Yogyakarta

Usia : 23 Tahun

Akun Instagram : : @rizkypersada

Gambar 6.

Profile Instagram Informan 2

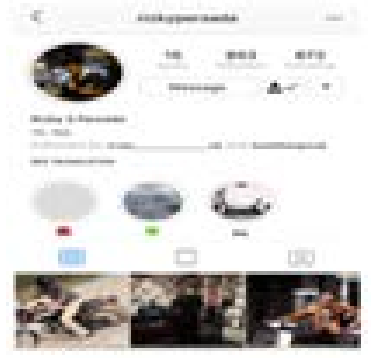

Sumber : akun instagram subjek penelitian 2 
Seorang Pria asal Yogyakarta ini merupakan Seorang Wirausaha Muda. Rizky termasuk orang yang pendiam dan sedikit tertutup. Rizky menggunakan media sosial Instagram sejak 2015. Alasan Rizky membuka akun Instagram awalnya untuk berjualan Online, karena rizky mempunyai sebuah usaha helm custom di Yogyakarta. Namun tidak jarang juga Rizky membagikan foto, mengabadikan momen hingga curahan hatinya melewati qoutes-quotes bahasa jawanya. la mengaku nyaman dengan pengungkapan diri yang dilakukannya melalui di Instagram Stories. la menuturkan bahwa dirinya lebih senang berbagi lewat Instagram Stories untuk media promosi dan sekedar berbagi kesehariannya. Dalam satu hari, Rizky dapat mengunggah 2-5 Stories. Hal-hal yang Rizky unggah adalah mengenai kegiatannya, produk jualan, kulineran dan teman-temannya.

\section{Hasil Penelitian dan Pembahasan}

\subsection{Tampilan Self Disclosure Melalui Unggahan Instagram Stories}

1. Informan 1 (Icak)

- Aspek Ketepatan

\section{Gambar 7.}

Instagram Stories Informan 1 Mengenai Aspek Ketepatan

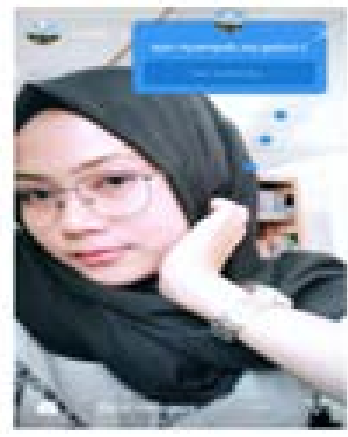

Sumber : akun instagram subjek penelitian 1

Unggahan Icak pada tanggal 16 maret 2019 adalah unggahan ekspresi wajah Icak di dalam sebuah ruangan yang sepi. Hal ini membuktikan bahwa Icak sedang mengungkapkan dirinya yang sedang bosan atau sedang tidak ada kegiatan sehingga Icak mengungkapan diri dengan memanfaatkan fitur Instagram Stories. Hal ini termasuk kedalam aspek pengungkapan diri dimana ketika terdapat indikator individu ini mengungapkan diri nya sesuai dengan keadaan atau situasi yang sedang ia hadapi. Selain itu informan ini juga menyadari apa yang sedang ia ungkapkan, dibuktikan dengan ia menggunakan foto dan menambahkan fitur Instagram Stories dengan"ask me questions" dimana fitur ini berfungsi ini memancing teman-temannya untuk mengomentari dari unggahan Icak. Alasan Icak menggunakan fitur 'ask me question' dengan menambahkan pertanyaan 
'ayo nyampah aq gabut' hal ini diperkuat dengan posisi informan yang sedang sendiri dan berada di dalam suatu ruangan yang sepi hal tersebut yang membuat Icak merasa kesepian. Dalam wawancara online Icak menyatakan bahwa :"ya menurut saya sering menggunakan IG Stories agar orang-orang tau sama aktivitas saya. Dan saya melakukan itu biar hati saya senang aja. Apalagi saya suka selfie wkwkwkw"

Jika menurut Devito (2011:64) pengungkapan diri dapat dilakukan kepada orang yang sudah dikenal dekat dan dipercaya, namun pada kenyataannya hal ini sesuai dengan yang dilakukan Icak. Alasannya ia lebih senang membagikan kisahnya dalam sosial media Instagramnya melalui fitur Instagram Stories untuk menarik perhatian terhadap teman-teman Instagramnya.

- Motivasi

Gambar 8.

Instagram Stories Informan 1 Mengenai Motivasi

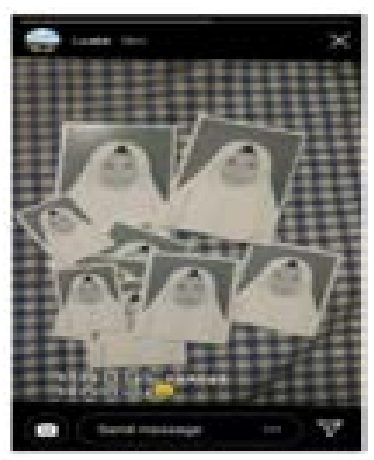

Sumber : akun instagram subjek penelitian 1

Unggahan Icak memposting beberapa foto dari ukuran besar hingga kecil yang berjumlah 9 foto. Informan 9 juga menambahkan caption yang bertuliskan "Bismillah, semoga beruntung" beserta emoticon senyum. Icak sedang merasakan sesuatu yang berasal dari dalam dirinya sendiri sehingga hal tersebut mendorong Icak untuk memposting hal tersebut melalui akun Instagram Storiesnya karena ia sedang berada dalam suasana yang jenuh dan membuat dirinya merasa harus mengungkapkan hal tersebut agar perasaan yang sedang ia rasakan saat itu menjadi lebih baik dengan ia memposting foto tersebut. Jika menurut Altman \&Taylor (Ifdil \&Zarian, 2013:113) Motivasi berkaitan dengan apa yang mendorong orang untuk mengungkapkan dirinya kepada orang lain. Hal ini sesuai dengan apa yang dilakukan oleh Icak. Hal ini diperkuat dengan hasil wawancara dimana Icak menyatakan bahwa :

"kalo akusih kenapa pakai Instagram stories karena tujuan pertama aku 
biar teman-teman tau aktivitasku sehari-hari ajasih hehe, terus biasanya kan juga sebagai hiburan aku kayak pas lagi ga ada temen gitu, biasanya aku pasti aktif di instagram stories terus update-update gitu, kan pasti abis itu orangorang pada bales update-an stories aku gitu di dm (direct message) lewat replyreply gitu..."

Cara ia mengungkapkan isi hatinya dalam Instagram Stories, menurut Icak dapat menimbulkan tanggapan dan solusi mengenai apa yang sedang terjadi dengan dirinya sehingga dapat memberikan ketenangan bagi dirinya sendiri.

- Waktu

Gambar 9.

Instagram Stories Informan 1 mengenai Waktu

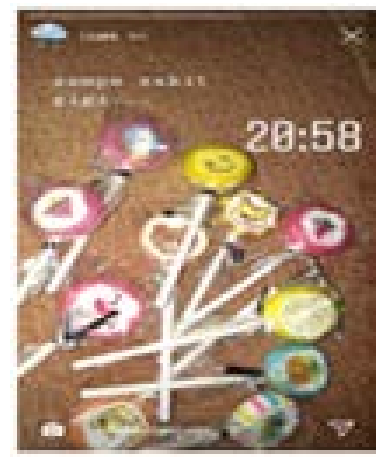

Sumber : akun instagram subjek penelitian 1

Icak memposting sebuah macam-macam permen dengan model yang berbeda. Icak terlihat menambahkan sebuah caption "sampe sakit gigi" menurut peneliti, informan 1 sedang mengungkapkan dirinya melalui permen tersebut sebagaimana ia mengkombinasikan foto permen tersebut dengan captionnya agar followers-nya mengerti bahwa Icak adalah orang yang suka makan permen sehingga akhirnya ia sakit gigi. Selain itu Icak juga menambahkan waktu dengan menggunakan fitur Instagram Stories, ia menambahkan waktu pada pukul 20.58 WIB. Hal ini menunjukkan bahwa ia memposting foto tersebut pada malam hari berdasarkan perasaan pada saat itu. Menurut Altman \&Taylor (Ifdil \&Zarian, 2013:113), waktu yang tepat untuk mengungkapkan diri adalah saat individu sudah berteman sejak lama dengan orang lain dan jika individu dalam keadaan baik seperti sedang sehat dan bahagia, ia akan cenderung terbuka dengan orang lain. Hal ini diperkuat dengan hasil wawancara dimana Icak menyatakan bahwa:"Kalo aku sih biasanya sesuai kondisi ya karena setiap aku melakukan aktivitas pasti aku upload tapi biasanya aku lebih sering selfie, kalo ditanya persennya sih 98\% lah ya wkwkw"

- Keintensifan 
Gambar 10.

Instagram Stories Informan 1 Mengenai Keintensifan
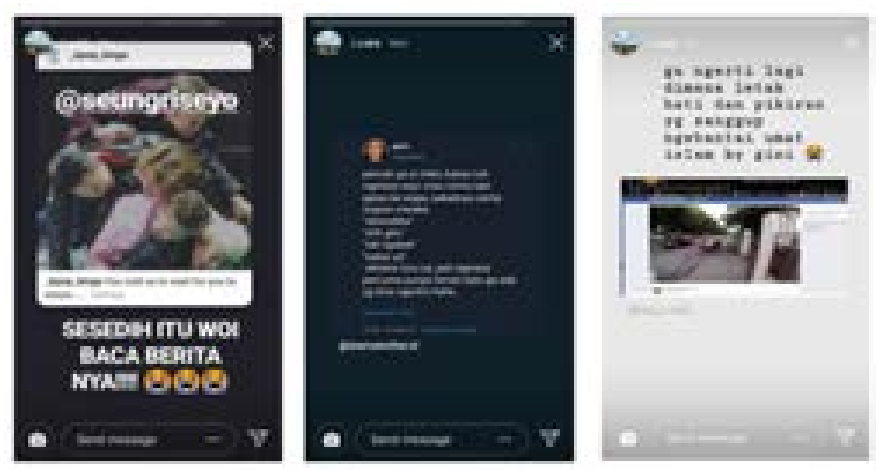

Sumber : akun instagram subjek penelitian 1

Menurut Suriana, keintensifan seseorang dalam pengungkapan diri tergantung kepada siapa seseorang mengungkapkan dirinya Menurut Suriana (dalam Eka Dewi 2013 :4), keintensifan seseorang dalam pengungkapan diri tergantung kepada siapa seseorang mengungkapkan dirinya. Icak sering me-repost berita-berita atau informasi yang sedang viral di IG Story nya. la juga ikut mengomentari dari postingan yang ia unggah untuk mengungkapkan rasa yang sedang ia rasakan ketika melihat informarsi yang sedang ia baca. Secara keintensifan pada postingan Icak ia sering mengunggah informan-informan yang sedang viral dan juga pemberian motivasi ke semua followers-nya. Unggahan yang diposting Icak, ia lebih intens memposting sebuah informasi kepada teman-teman dekatnya,teman biasa, maupun teman yang baru dikenalnya di Instagram. Hal ini didukung dari pernyataan Icakdalam wawancara ia menyatakan bahwa :" $\mathrm{hmmm}$ kalo yang aku lihat dari last seen aku sih biasanya seimbang sih. Karena rata-rata juga ada yang 50\% nya aku kenal dan ada juga yang ga aku kenal sisanya walaupun orang-orang itu masuk kedalam daftar pertemanan di Instagram aku". Hasil penelitian menunjukkan bahwa Icak adalah orang yang terbuka di dalam media sosialnya. Karena dengan ia tidak mengenal sebagian dari orang-orang yang melihat Instagramnya, ia berani melakukan pengungkapan diri secara intens.

- Kedalaman

\section{Gambar 11.}

Instagram Stories Informan 1 Mengenai Kedalaman

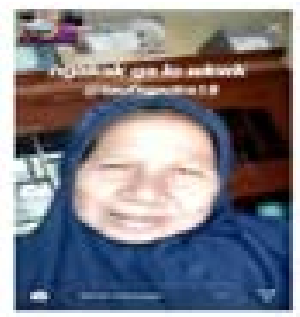

Sumber : akun instagram subjek penelitian 1 
Icak merupakan orang yang sering mengungkapkan dirinya ke Instagram Stories. Biasanya Icak ini melakukan pengungkapan diri nya biasanya mengenai hal-hal umum. Icak memposting sebuah screenshoot video call melalui aplikasi whatsaap. Dalam postingan tersebut, Icak menuliskan caption "ngakak ga lo wkwkkww @taufiqputra18” di dalam foto tersebut terlihat Icak tidak mengungkapkan diri dengan fotonya sendiri melainkan seorang wanita tua berjilbab dan tidak berjilbab. Menurut hasil observasi, itu adalah bukti komunikasi diantara orang tua Icak dan teman cowoknya. la memposting hal tersebut agar followers-nya di Instagram Stories tahu bahwa orang tuanya sudah akrab. Jika menurut Altman \&Taylor (Ifdil \&Zarian, 2013:113), Kedalaman terbagi atas dua dimensi yaitu Self disclosure yang dangkal dan dalam. Hasil observasi peneliti dengan apa yang di posting pada Icak mengenai kedalamannya termasuk kedalaman Self disclosure yang dalam, karena di dalam postingannya terdapat ia menyebutkan nama akun seseorang. Hal tersebut menunjukkan ada pesan tersendiri yang ingin ia sampaikan kepada akun tersebut.

\section{Informan kedua (Rizky)}

- Ketepatan

Gambar 12.

Instagram Stories Informan 2 Mengenai Ketepatan
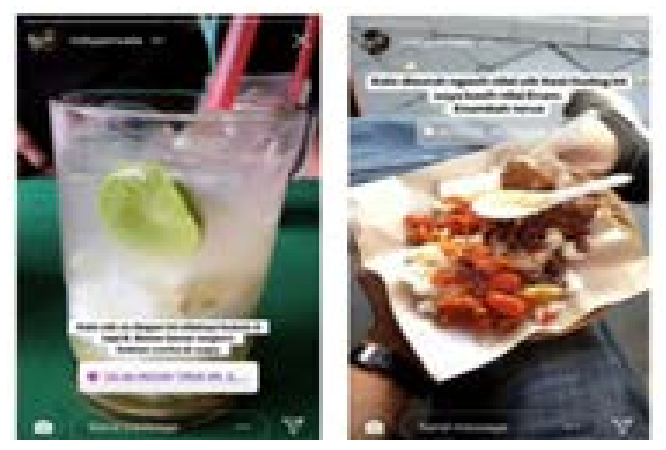

Sumber : akun instagram subjek penelitian 2

Rizky mengunggah foto makanan Gudeg, dimana dalam foto tersebut ia terlihat memangku nasi gudeg tersebut. Kemudian didalam unggahannya ia menambahkan caption yang bertuliskan :"Kalo disuruh ngasih nilai untuk nasi gudeg ini, saya kasih nila enam. Enambah terus". Dimana pada kata-kata pertama ia menilai nasi gudeg tersebut dengan nila yang rendah yaitu 6. Akan tetapi ia peleseti dengan kata-kata "Enambah terus" hal tersebut dapat membuat followers-nya yang membaca terhibur. Selain itu dalam postingan pertama ia menambahkan lokasi di daerah kotagede, yogyakarta. Sama halnya dengan gambar yang kedua, ia juga memposting sebuah minuman segar dimana ia juga menuliskan sebuah caption lucu yaitu "Kalo untuk es degan ini nilainya A tapi B. Bener-bener segerrr. Sekian cerita dari saya."Dengan Informan menambahkan fitur Instagram Stories yaitu "lokasi" hal tersebut membuat ketepatan yang dilakukan Rizky sesuai dengan teori menurut Altman \& Taylor (Ifdil \& Zarian, 2013:113) bahwa 
postingan yang relevan ketika keadaan yang sedang ia hadapi sesuai dengan individu yang bersangkutan terlibat atau tidak (sekarang dan di sini) dalam sebuah peristiwa, sesuai dengan norma-norma yang berlaku di masyarakat dalam menggunakan media sosial. Rizky ini bertujuan untuk menghibur followers-nya dengan pengungkapan diri yang menarik melalui caption-captionnya. Sehingga followers-nya tidak jarang untuk berkomentar atas unggahannya yang menarik perhatian. Berdasarkan hasil wawancara peneliti dengan Rizky ia menyatakan bahwa :

"Buat mengabadikan moment-moment aja tapi kadang aku juga suka hal-hal anti mainstream gitu wkwkw kaya ga serius-serius banget di Stories hanya buat hiburan aja, kadang kalo yang aku unggah lucu pasti temen-temen suka gitu jadi itung-itung sekalian cari pahala aja sih wkwkw"

Hasil observasi menunjukkan bahwa yang dilakukan Rizky masih sebatas wajar dan ia termasuk kedalam orang yang underdisclosure atau orang yang tidak terlalu sering melakukan pengungkapan diri di Instagram Stories.

- Motivasi

Gambar 13.

Instagram Stories Informan 2 Mengenai Motivasi
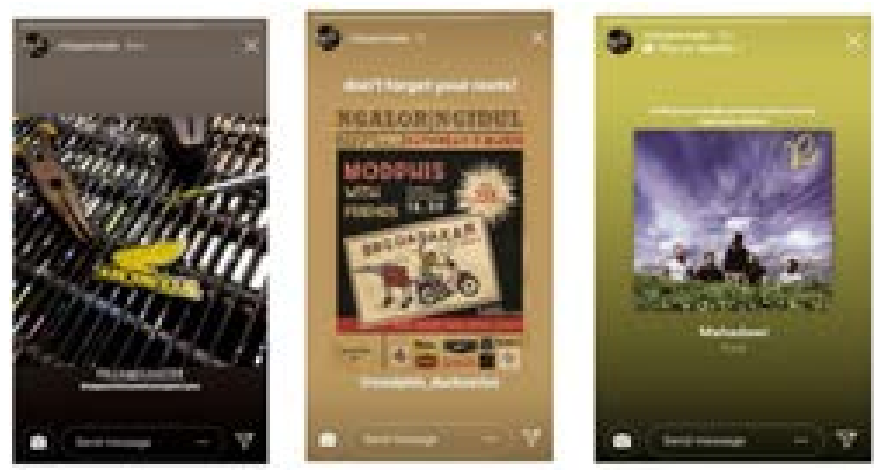

Sumber : akun instagram subjek penelitian 2

Dalam positngan Rizky, terdapat 3 postingan yang merupakan pengungkapan diri yang berasal dari Rizky sendiri. Gambar pertama, terlihat postingan foto berupa tang dan pin bertuliskan "Honda". Kemudian didalam foto tersebut terdapat informan men- tag sebuah nama akun instagram bernama “@kingpins264" dan dibawahnya menuliskan caption \#supportthosewhosupportyou. Hal ini merupakan motivasi informan karena dorongan untuk menginspirasi dan bisa juga mempromosikan followers-nya agar ketika ingin mencari pin custom bisa langsung ke akun tersebut. Alasan Rizky mempostingan foto tersebut, hal ini berdasarkan dorongan dari luar yaitu untuk membantu rekan kerjanya.Gambar kedua, Rizky memposting sebuah pamflet acara. Dimana di dalam postingan pamflet tersebut Rizky menambahkan caption 
"dont forget yout roots!" dan menambahkan tag kepada akun instagram miliki @ modphis_dusckseries. Hal ini terlihat bahwa motivasi Rizky karena dorongan dari luar yaitu dari temannya yang memiliki profesi yang sama dengan Rizky. Sedangkan, gambar 3, Informan memposting sebuah lagu yang berasal dari aplikasi musik yaitu Spotify. Rizky terlihat sedang mendengarkan lagu dari Band Indonesia yang terkenal yaitu PADI dengan judul lagu Mahadewi. Kemudian didalam postingan informan 3 ia menambahkan caption yang bertuliskan dalam bahasa jawa : "Kelingan kakangku ponakan gitaran neng ngarepan dadian" yang artinya "Keinget kakak ponakan gitaran di depan orang jadian". Maksud dari caption Rizky yaitu dengan ia mendengarkan lagu tersebutmengingatkan ia pada suatu kejadian dimana kakak keponakannya sempat nyanyi di depan orang jadian dengan lagu padi-mahadewi tersebut. Hal ini menunjukkan bahwa Rizky melakukan unggahan tersebut berasal dari dirinya sendiri tanpa disadari lagu tersebut mengingatkannya pada sebuah kejadianya yang sebelumnya tidak sedang ia pikirkan.

- Waktu

Gambar 14.

Instagram Stories Informan 2 Mengenai Waktu

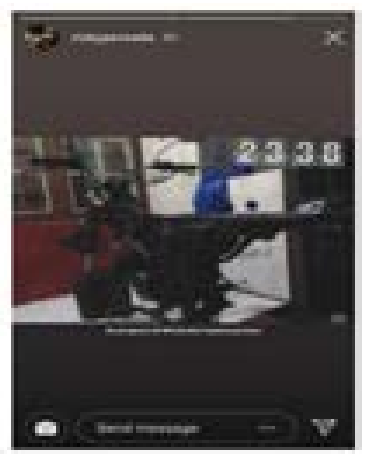

Sumber : akun instagram subjek penelitian 2

Terlihat dalam postingan yang di unggah Rizky yaitu, sebuah foto kerangka motor di dalam rumah. Rizky juga menambahkan caption pada foto tersebut yang bertuliskan "On progress Si Winda biar sepatunya baru" yang artinya motor tersebut sedang dalam proses untuk diganti jadi sebuah badan motor yang baru dan winda itu adalah julukan bagi motor kesayangan Rizky. Selain itu, Rizky juga menambahkan jam pada postingan tersebut yaitu 23.38 WIB itu menandakan Rizky memposting gambar tersebut pada malam hari dan sesuai dengan kondisi atau situasi saat itu. Berdasarkan hasil wawancara dimana Rizky selama mengunggah sesuatu berdasarkan kenyataan atau tidak, ia mengungkapkan bahwa : "Beberapa hari kemarin ga pernah begitu hahah" Hasil observasi menemukan adanya ketidaktepatan dalam unggahan Rizky ini berdasarkan apa yang peneliti amati sebelumnya. Hasil dari yang peneliti amati, peneliti melihat Rizky lebih sering menguggah foto atau gambar yang bukan berasal dari take atau record fitur Instagram Stories. 
- Keintensifan

Gambar 15.

Instagram Stories Informan 2 Mengenai Keintensifan
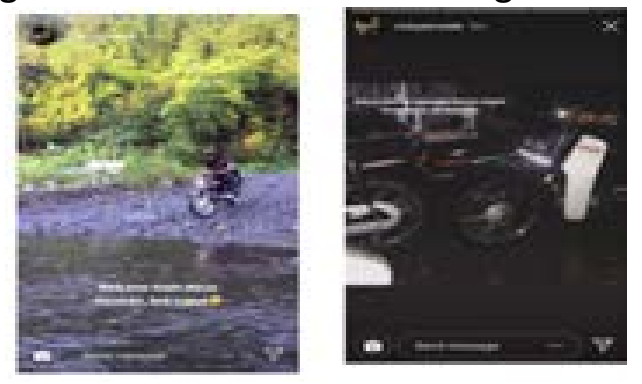

Sumber : akun instagram subjek penelitian 2

Dalam postingan yang di unggah kedalam Instagram Stories Rizky ini biasanya ia memposting mengenai hobi dan produk jualannya berupa usaha otomotif. Rizky jarang sekali mengungkapkan diri melalui dirinya sendiri. la lebih sering mengungkapkan dirinya dengan mengunggah motor-motor dan produk usahanya saja. Dalam melakukan pengungkapan diri pun menurut peneliti Rizky ini hanya sekedar mengungkapkan diri biasa, karena ia lebih sering menggunakan Instagram Storiesnya hanya untuk berbagi momen-momen yang menurutnya penting. Hal ini ia nyatakan dalam wawancaraonline yang menyatakan bahwa :"aku sih biasanya kalo buat ig stories kalo pas ada momentnya aja. Kalo ga ada ya ga buat. Tapi kadang kalo buat pun hanya untuk media promosi aja. Ada waktu dimana saya memposting diri saya ketika saya pengen aja haha"

Berdasarkan diatas hasil observasi menunjukkan bahwa Rizky ini merupakan orang yang menggunakan Instagram Stories hanya seperlu saja. Dengan pernyataan nya seperti itu, ketika peneliti mengamati postingan yang di unggah selebihnya normal dan tidak begitu berlebihan. Berdasarkan aspek keintensifan Rizky ini lebih sering mengunggah momen-momen penting dan produk usahanya untuk ditujukan kepada semua followersnya.

- Kedalaman

Gambar 16.

Instagram Stories Informan 2 Mengenai Kedalaman

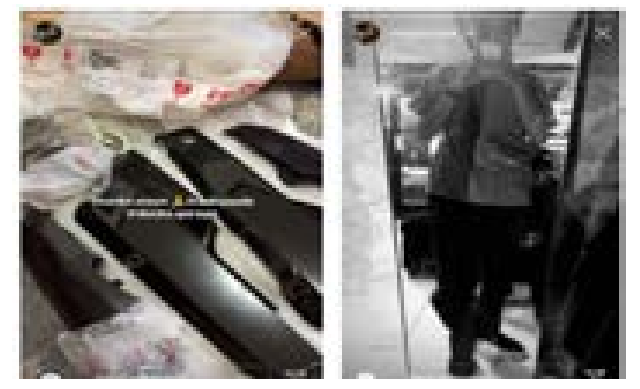

Sumber : akun instagram subjek penelitian 2 
Dalam postingan Rizky kali ini ia memposting sebuah foto yang berasal dari sebuah paketan yang isinya adalah badan dari sebuah motor. Dalam foto tersebut terdapat 4 badan motor yang baru. Kemudian Informan menuliskan caption "Thanks mase" dengan menambahkan emot berbentuk tangan. Informan juga menggunakan fitur tag kepada nama akun instagram yaitu @adityaatb dan @duck.garage. Disini terlihat bahwa Rizky membagikan postingannya untuk mengucapkan terimakasih atas barang yang sudah sampai di tangannya yang berasal dari akun instagram @adityaatb dan @ducks.garage. Akun @adityaatb adalah temannya kerjanya dan @ducks.garage adalah toko dari temannya tersebut. Hal ini ia unggah jelas untuk kepada akun tertentu yaitu temannya sendiri. Gambar Kedua, Rizky terlihat sedang mengungkapkan diri melalui fotonya sendiri dengan caraselfie. Pamela Rutledge (2013: 9) menjelaskan Selfie adalah perilaku memotret diri sendiri atau self portrait yang biasanya dilakukan menggunakan kamera ponsel, dan kemudian diunggah ke sosial media. Menurut peneliti, tujuan Rizky melakukan pengungkapan diri tersebut untuk membagikan aktivitas yang sedang ia lakukan pada saat itu untuk memberitahu kepada teman-temannya di Instagram.

\section{Simpulan}

1. Pengungkapan diri (Self disclosure) yang dilakukan oleh kedua informan termasuk kedalam dimensi Pengungkapan diri (Self disclosure) yang tepat dan maksimal karena sudah memenuhi ke 5 aspek Self disclosure yaitu ketepatan, motivasi, waktu, keintensifan dan kedalaman. Bahwa orang yang sudah tepat dalam melakukan pengungkapan diri ini terbukti mampu menyesuaikan diri (adaptive), lebih percaya diri sendiri, lebih kompeten, dapat diandalkan, lebih percaya kepada diri sendiri, lebih mampu bersikap positif, lebih objektif, percaya terhadap orang lain dan terbuka.

2. Tujuan Remaja melakukan pengungkapan diri melalui media sosial Instagram pada fitur Instagram Stories yaitu untuk mengikuti trend,media promo, mengabadikan momenmomen penting dan untuk media interaksi dan komunikasi bersama teman-teman.

\section{Daftar Pustaka}

Ardianto, Elvinaro. 2007. Komunikasi Massa Suatu Pengantar. Bandung: Simbiosa Rekatama Media.

Devito, Joseph. 2011. Komunikasi Antar Manusia. Tangerang: Karisma PublishingGroup.

Hine, Christine. (2000). Virtual Etnhography. London, Thousand Oaks, New Delhi : SAGE Publication

Ifdil. (2013). Konsep Dasar Self Disclosure dan Pentingnya bagi Mahasiswa Bimbingan dan Konseling. Jurnal Ilmiah Pendidikan (Nomor 1 Tahun 2013). Universitas Negeri Padang. HIm. 110-117. 
Nasrullah, Rulli. 2014. Teoridan Riset Media Siber(Cybermedia). Jakarta :Kencana Prenadamedia Group.

Novianna, Ruth Permatasari \& A.M Heru Basuki. (2010). Self Disclosure in Adolescent Who Have Devorced Parents. (Thesis) Depok : Universitas Gunadarma.

Trenholm, Sarah \& Arthur Jensen. Interpersonal Communication. California (Wadsworth, 2004)

Internet

Emarketer. (2018). Pengguna Internet Indonesia Nomor enam di Dunia.https://kominfo.go.id/ content/detail/4286/pengguna-internet-indonesia-nomor-enam-dunia/0/sorotan media, diunduh tanggal 14 Juni 2019 pukul 15.49

Hani Nur. 2016. Ada 22 Juta Pengguna Aktif Instagram dari Indonesia. https://www. cnnindonesia.com/teknologi/20160623112758-185-140353/ada-22-juta-penggunaaktif-instagram-dari-indonesia, diunduh tanggal 27 Juni 2019 pukul 17.15

Anonim. 2017. Data Pengguna Instagram Per Umur. https://kekitaan.com/layanan-kita/datapengguna-instagram-per-umur/, diunduh tanggal 12 Juni 2019 pukul 10.00

Anonim. 2018. Pernah Dapat pelecehan Istri Gilang Dirga Neggak kapok Main Medsos. https:// kumparan.com/@kumparanhits/pernah-dapat-pelecehan-istri-gilang-dirga-enggakkapok-main-medsos, diunduh tanggal 27 Juni 2019 pukul 20.10

Heribertus. 2018. Dian Sastro Banjir Bully Gara gara Foto ini Netizen Merasa Tertipu dengan Sosoknya. http://lampung.tribunnews.com/2018/03/18/biasa-dipuja-dian-sastrobanjir-bully-gara-gara-foto-ini-netizen-merasa-tertipu-dengan-sosoknya, diunduh tanggal 13 April 2019 pukul 09.56

Aswab Nanda. 2018. Hari Ini dalam Sejarah Aplikasi Instagram Dirilis. https://tekno.kompas. com/read/2018/10/06/10512437/hari-ini-dalam-sejarah-aplikasi-instagram-dirilis, diunduh tanggal 20 mei 2019 pukul 18.10

Wahyunanda. 2018. Riset Ungkap Pola Pemakaian Medsos Orang Indonesia. https://tekno. kompas.com/read/2018/03/01/10340027/riset-ungkap-pola-pemakaian-medsosorang-indonesia, diunduh tanggal 1 Maret 2019 pukul 17.10

Anonim. 2018. Infografis Platform Media Sosial Paling Aktif di Indonesia. https://www. validnews.id/infografis-Platform-Media-Sosial-Paling-Aktif-Di-Indonesia-QJ, diunduh tanggal 12 Juni 2019 pukul 08.25 